\title{
FISCAL SOVEREIGNTY vS. HARMONIZED FISCAL POLICIES. APPLICATION OF SPLIT VAT IN ROMANIA - A FAILED PROJECT. COMPARATIVE LAW
}

\author{
Ramona CIOBANU ${ }^{1}$
}

\begin{abstract}
Each Member State of the European Union establishes its own fiscal policy, under its sovereignty, according to its interests. Nevertheless, requirements such as the proper operation of the Single Market, the protection of fair competition, the fight against aggressive tax planning and against tax evasion, the stability of the European Economic Area have led to the adoption of European rules on the harmonization of the Member States' tax laws, with an emphasis on indirect taxes. Implementation mechanisms have been established so that non-compliance with them leads to the inapplicability of the non-harmonized internal rules. This is also the case for Romania's unsuccessful attempt to apply split VAT, while other Member States apply this method of VAT payment/collection.
\end{abstract}

Key words: tax sovereignty, harmonized rules, direct taxes, indirect taxes

\section{Content of the Notion of Sovereignty}

Over time, several ideas, conceptions, theories regarding sovereignty have been formulated in an attempt to answer questions such as what sovereignty is and what the content of the notion of sovereignty is. In general, sovereignty is defined as the right of the state to decide freely in its internal and external affairs, without interference from other states and concerns the characteristic of the power to be supreme on the territory of the state and independent of any foreign power.

In the context of globalization, international cooperation, on the one hand, international fragmentation and the formation of new independent states, on the other hand, the theme of sovereignty always remains current because sovereign states continue to be the main actors in the international system.

However, the attribute of sovereignty does not mean disobedience of the international order, non-compliance with the international law, because the

1 Senior Lecturer, Ph.D., Faculty of Law, Law Department, Transilvania University of Braşov, ramona.ciobanu@unitbv.ro, 
establishment and development of international relations is possible only through cooperation, in compliance with international norms. Besides, the fundamental principles of public international law, laid down in the UN General Assembly Resolution no. 2625/1970, the Helsinki Final Act 1975 and the Paris Charter for a New Europe 1990, is a strong guarantee of respect for sovereignty.

In the legal doctrine, as well as in that of international relations, the notions of national sovereignty, people's sovereignty, state sovereignty or simply sovereignty are used.

Romanian legal literature defines national sovereignty as the right of each nation to self-determination and independent development, whether or not it has its own state organization. When the nation sets up as an independent and sovereign state, national sovereignty identifies with state sovereignty (Muraru, 1995, p.150).

People's sovereignty is people's right to determine their own destiny, to establish the political line of the state, the composition of its organs and to control their activity. In societies in which state power belongs to the entire people, the sovereignty of the people is identified with the sovereignty of the state (Muraru, 1995, p.150).

State sovereignty is the supremacy and independence of power in expressing and giving effect to the will of the rulers as a compulsory will for the whole society (Muraru, 1995, p.152). Defining the content of sovereignty through supremacy and independence concerns the existence and realization of power as sovereign power and contributes to the understanding of the notion of sovereignty. While supremacy concerns the property of state power of being superior to any other power in relations with the population within the limits of state power, independence concerns that property of state power of not being limited in the accomplishment of its aims and tasks by any foreign state power (Muraru, 1995, p.152).

Sovereignty is incompatible with any limitation of the sovereign rights of States, but international cooperation and participation in the international system presuppose rights and obligations, within the international law, according to the treaties concluded by the States. At the same time, the international climate of cooperation, trust, peace and security, to which the international organizations with a vocation for universality and the regional ones, defined as associations of states, contribute significantly, is an important guarantee for the independence and sovereignty of states.

\section{Compatibility of the European Union's Fiscal Policy with the Fiscal Sovereignty of the Member States}

The establishment of the three European communities was inspired by the need to reconcile the European states on different barricades in World War II, by the conviction of the founding states that they must build a common future, that economic integration will bring political integration and that together they will be stronger.

The European Coal and Steel Community (Treaty of Paris) signed in 1951 and entered into force in 1952 laid the foundations of community building through the institutions created and was the first step towards integration. The treaty was concluded for a fixed period of 50 years and was to create the pattern for the expansion of cooperation in 
other areas of the economy, the ECSC being thought of as the beginning of the federalization of Europe.

The Treaties establishing the European Economic Community and the European Atomic Energy Community (the Treaties of Rome) concluded in 1957 and entered into force in 1958, aimed at long-term economic cooperation, being concluded for an indefinite period; moreover, they aimed, on the one hand, at establishing a Common Market and, on the other hand, at creating the framework for the peaceful use of atomic energy.

Steps were taken towards deeper and deeper integration, the number of members increased, new treaties were concluded, existing institutions were reformed, new ones were created, areas of competence were rethought, and hence the political and economic organization of today, the European Union, was built. Member States agreed, by the Constitutive Treaties or by accession, to transfer part of their powers to the Union institutions so that the latter take supranational decisions, which are binding in the areas established within the Union. These fields have been established through negotiations and the Union is acting on behalf of the Member States only to the extent and in fields where they have agreed and conferred powers on the Union to do so (Miga-Beșteliu, 2000, p. 18), this regional organization being conceived as a supranational integration organization, not as a cooperation organization.

With regard to fiscal policy, each Member State is free to establish its own fiscal policy and tax system, according to its interests, on the basis of fiscal sovereignty as part of state sovereignty, with the Union having limited powers.

Even in these circumstances, Member States must uphold the principle of subsidiarity and observe the Code of Conduct for Business Taxation (Eberhartinger \& Six, 2007, p. 213). As regards the Code, this is a political commitment by Member States to reexamine, amend or abolish their existing tax measures that constitute harmful tax competition (rollback process), on the one hand and on the other hand, to refrain from introducing new ones in the future (standstill process).

European tax rules therefore aim at a certain coordination of Member States' fiscal policies, which could ensure support for the wider objectives of the Union. The founders were convinced that the allocation of resources in the EU is done through competition so that in order to avoid its distortion it is necessary to harmonize the fiscal policies of the Member States (Cnossen, 2002, p. 13). The harmonization of the fiscal rules of the Member States was oriented towards indirect taxes, respectively VAT, excise duties, import customs duties, environmental taxes, in order to ensure the proper functioning of the Single Market.

The problems faced by the Member States, such as aggressive tax planning, the digital economy, tax evasion and money laundering; have led to the need for Union-wide measures to ensure a unified response to these problems. Harmonization has also begun to cover direct taxes, namely taxes on the income of individuals and legal entities, and plans have been put in place to protect the financial interests of the Member States of the Union and to protect competition in the Single Market (Birch, 2001, p. 143-195).

EU fiscal policy strategy (European Commission, COM/2001/260) seeks to eliminate fiscal obstacles hindering cross-border economic activity, the fight against harmful tax 
competition, tax evasion and fraud, transparency and cooperation between the Member States' tax administrations. It is worth noting the procedure for adopting European tax rules.

In the EU Council, decisions and directives on European Commission Tax Proposals are adopted with unanimity, hindering cross-border economic activity, the fight against harmful tax competition, tax evasion and fraud, transparency and cooperation between Member States' tax administrations. That is why the Commission's proposal to replace unanimity by a qualified majority as a rule for the adoption of certain rules on taxation was rejected by the Member States.

\section{Application of split VAT in Romania}

VAT is an indirect tax, with instalment payment, having a fixed rate, established on the added value in each stage of the economic circuit (Șaguna \& Șova, 2008, p. 188). It can have a high tax return because it is borne by all beneficiaries of taxable transactions and does not require high collection costs.

According to the Directive 1967/2/CEE Council, the value added tax is the main indirect tax in the EEC, with the Member States being required to introduce this tax into national law. In 1977, harmonization of Member States' VAT legislation was achieved, the presence of this tax in domestic law being a condition for joining the organization.

The Directive 2006/112/CE Council Directive of 28 November 2006 on the common system of value added tax lays down rules on the object and scope of VAT, territorial scope, taxable persons, taxable transactions, place of taxable transactions, the generating fact and the chargeability of VAT, exemptions, deductions, obligations of taxable persons and certain non-taxable persons, special arrangements and derogations.

The common system of VAT is necessary to lead, even if quotas and exemptions are not fully harmonized, to competition neutrality, so that, in the territory of each Member State, similar goods and services bear the same tax burden, regardless of the length of the production and distribution chain.

At the same time, the preamble to the Directive states that the obligations of taxable persons need to be harmonized in order to ensure the necessary guarantees for the collection of VAT in a uniform manner in all Member States.

Notwithstanding these common rules, the Directive establishes the right of Member States to introduce and apply, within certain limits and subject to certain conditions, special derogating measures in order to simplify the collection of the tax or to prevent tax evasion. This way, art.395 of the Directive regulates the procedure for authorizing the introduction of derogating measures from the common system of VAT.

VAT is considered the most modern form of taxation, being applied in over 160 states worldwide. Although it can be highly efficient, this advantage can be eroded by fraudulent procedures, which is why states take fiscal measures to protect public finances. In this sense, the attempt to introduce VAT split in Romania is also included (Ciobanu, 2019, p. 23-27).

Split VAT consists in using a special VAT account in which to collect the VAT from the beneficiaries and from which to pay the tax to the budget and to the suppliers, 
respectively. Consequently, the recipient of the goods or services will have to perform two operations: payment of the value of the goods and services in the current account of the supplier and payment of the VAT related to them in the VAT account. If he does not have sufficient resources in his own VAT account to pay the tax to the supplier, he will transfer the amount corresponding to the VAT due from his own current account.

Also from the VAT account the payment of the tax due to the state budget will be made and, also in this account, upon request, the VAT refund will be made. In other words, this account is a mirror of the taxpayer's activity. VAT split in Romania was regulated by Government Ordinance no. 23/2017 regarding the broken-down payment of VAT, approved by Law no. 275/2017 and was applied optionally between 1 October 31 December, 2017 and mandatory starting with 1 January, 2018. VAT split applies to taxable persons for VAT purposes, including public institutions, if they had unpaid tax obligations above a certain level or were subject to insolvency rules.

The other taxpayers had the right to opt for the application of split VAT, the normative act also providing measures to stimulate the transition to this payment system, respectively the reduction by $5 \%$ of the profit tax and the due income tax of microenterprises, as well as the cancellation of penalties for late payment of VAT. The exit from the mandatory or optional VAT split regime was also regulated.

On 8 November 2018, the European Commission sent a letter of delay to Romania regarding the application of split VAT because in this alternative collection mechanism, VAT is transferred to a special blocked account, "causing a major administrative burden to honest companies operating there". The notification states that the measures are contrary to EU VAT rules (Council Directive 2006/112 / EC) and the freedom to provide services (article 56 of TFEU).

The letter of formal notice follows a communication from the European Commission on the same date, "rejecting Romania's request to derogate from EU rules in this area due to concerns arising from the principle of proportionality and compatibility with the Treaty. If Romania does not act within the next two months, the Commission may send a reasoned opinion to the Romanian authorities." Thus, 8 November 2018 marks the rejection of Romania's request to deviate from the European norms regarding the VAT split and the start of the initial stage of the infringement procedure.

Romania no longer applies the VAT split from 1 February 2020, when the Government Emergency Ordinance no. 78/2019 repealing the Government Ordinance no. 23/2017 is issued.

\section{Compared Law. Application of split VAT in Italy}

Romania is not the first state to have applied Split VAT in the EU, Italy has been applying this system since 1 January 2015 for the public institutions. Italy considered it appropriate to apply this derogating system from European rules to combat tax evasion, but it understood to do it in stages, for certain entities and in accordance with the procedure laid down by art. 395 in the Directive 2006/112/CE of the Council of 28 November 2006 on the common system of value added tax.

The significant reduction of tax evasion (Minnistero dell Economia e delle Finanze, Rapporto evasione fiscale 2021, p. 21) led to the successive extension of the VAT split 
application, the last extension being approved by the EU Council on 24 July 2020, at the proposal of the European Commission.

\section{Conclusions}

Failure to comply with European rules and procedures entails the inapplicability of fiscal measures adopted at national level, as the Union has mechanisms in place to block such measures.

The adoption and hasty application of fiscal measures, without a consistent public debate, without a careful assessment of their impact on the business environment, without giving it sufficient time to adapt to the new requirements and without complying with European rules, is likely to determine their failure, even if the intention is a good one, to consolidate the budget revenues, to increase the degree of their collection, Romania having serious difficulties in this regard, to reduce tax evasion.

\section{References}

Birch S. (2001). Tax coordination in the European Union: What are the issues. Swedish Economic Policy Review 8(2001), p. 143-195.

Ciobanu, R. (2019). Split TVA sau plata defalcată a TVA. Noțiune. Reglementare. Avantaje. Dificultăți de implementare [Split VAT or broken-down payment of VAT. Notion. Regulation. Benefits. Implementation difficulties]. Fiscal Courier no. 1/2019, p. 23-27

Cnossen, S. (2002). Tax Policy in the European Union: A Review of Issues and Options. CESIFO Working Paper Category 1: Public Finance, https://www.researchgate.net/publication/4788705_Tax_Policy_in_the_European_Un ion_A_Review_of_Issues_and_Options

Council of the European Union. Council Implementing Decision (EU) 2020/1105 of 24 July 2020. Official Journal of the European Union 242/4/28.07.2020

Eberhartinger, E., Six, M. (2007). National Tax Policy, The Directives and Hybrid Finance. In Andersson, K., Eberhartinger, E., Oxelheim, L. National Tax Policy in Europe. To Be or Not to Be?. Springer, p.213-236, https://link.springer.com/book/10.1007/978-3-54070711-0

European Commission. Communication from the Commission to the Council, the European Parliament and the Economic and Social Committee Tax policy in the European Union - Priorities for the years ahead /* COM/2001/0260 final */

Miga-Beșteliu, R. (2000). Organizații internaționale interguvernamentale [International Intergovernmental Organizations]. Bucharest: ALL Beck

Minnistero dell Economia e delle Finanze. Rapporto evasione fiscale 2021, p. 21, https://www.finanze.gov.it/export/sites/finanze/.galleries/Documenti/Varie/Rapporto _evasione_2021_25-Settembre_2020.pdf

Muraru, I. (1995). Drept constituțional și instituții politice [Constitutional Law and Political Institutions]. Bucharest: ACTAMI

Șaguna, D. D., Șova, D. (2008). Drept fiscal. Ediția 2 [Fiscal Law. Second Edition]., Bucharest: C.H. Beck 